DOI: https://doi.org/10.24127/ajpm.v10i4.3707

\title{
PERSEPSI GURU MATEMATIKA TERHADAP PEMBELAJARAN DALAM JARINGAN (DARING)
}

\author{
Rizka Juni Anisa', Padrul Jana ${ }^{2 *}$, Marsiyam \\ ${ }^{1,2}$ Universitas PGRI Yogyakarta, Yogyakarta, Indonesia. \\ ${ }^{3}$ SMK N 4 Yogyakarta, Yogyakarta, Indonesia. \\ *Corresponding author: Jl. IKIP PGRI I Sonosewu No.117, Kec. Kasihan, Bantul, Yogyakarta 55182 \\ E-mail: padrul.jana@upy.ac.id ${ }^{2 *)}$
}

Received 02 May 2021; Received in revised form 08 September 2021; Accepted 04 October 2021

\begin{abstract}
Abstrak
Selama pandemi wabah Covid-19, guru melakukan pembelajaran secara daring. Pembelajaran daring menjadi pilihan utama karena adanya pandemi ini. Penelitian ini bertujuan untuk mendeskripsikan persepsi guru terhadap pembelajaran daring pada mata pelajaran matematika. Persepsi guru yang digali meliputi aspek materi ajar, interaksi belajar, dan lingkungan belajar matematika dalam pembelajaran daring. Jenis penelitian ini termasuk dalam kategori kualitatif deskriptif. Pengambilan data penelitian menggunakan angket Google Form dan wawancara. Data diperoleh dari guru matematika tingkat SMP dan SMA sederajat di Daerah Istimewa Yogyakarta sebanyak 30 responden. Teknik analisis data yang digunakan yaitu reduksi data, penyajian data, penarikan kesimpulan. Selanjutnya dilakukan keabsahan data untuk mengecek data yang didapatkan dari angket dengan data wawancara menggunakan triangulasi. Hasil penelitian menunjukkan bahwa pada aspek materi ajar persepsi guru dalam kategori baik. Pada aspek interaksi belajar menurut persepsi guru matematika itu dalam kategori kurang. Hal ini karena tidak semua siswa menjadi aktif ketika pembelajaran daring berlangsung. Sedangkan pada aspek lingkungan belajar guru memiliki persepsi kurang. Hal ini juga di dukung oleh pendapat guru bahwa lingkungan belajar selama pembelajaran daring lebih susah dikondisikan karena tidak bertatap muka secara langsung, sehingga guru susah untuk memantau siswanya.
\end{abstract}

Kata kunci: Matematika; Pembelajaran Daring; Persepsi Guru.

\begin{abstract}
During the Covid-19 pandemic, teachers conducted online distance learning. Online learning the main choice because of this pandemic. This study aims to describe the teacher's perceptions of learning online on mathematics. Teacher perceptions that are explored include aspects of teaching materials, learning interactions, and the mathematics learning environment in online learning. This type of research is included in the descriptive qualitative category. Retrieval of research data using a questionnaire Google Form and interviews. Data obtained from mathematics teachers at the junior and senior high school levels in the Special Region of Yogyakarta as many as 30 respondents. The data analysis technique used was data reduction, data presentation, and conclusion drawing. Furthermore, the validity of the data was carried out to check the data obtained from the questionnaire with interview data using triangulation. The results showed that in the aspect of teaching material, the teacher's perception was in a good category. In the aspect of learning interaction, according to the mathematics teacher's perception, it is in a low category. This is because not all students become active when online learning takes place. Meanwhile, in the aspect of the learning environment, teachers have fewer perceptions. This is also supported by the teacher's opinion that the learning environment during online learning is more difficult to the condition because it does not meet face to face so that it is difficult for teachers to monitor their students.
\end{abstract}

Keywords: Mathematics; Online Learning; Teacher Perception.

This is an open access article under the Creative Commons Attribution 4.0 International License 
DOI: https://doi.org/10.24127/ajpm.v10i4.3707

\section{PENDAHULUAN}

Pendidikan merupakan suatu proses komunikasi dan formasi dari pendidik kepada peserta didik (Mutia \& Leonard, 2013). Melalui pendidikan diharapkan hasil yang dicapai oleh peserta didik memiliki kecerdasan intelektual dan spiritual sebagai modalnya untuk hidup bermasyarakat.

Pada tahun 2020 tepatnya awal Maret, Indonesia di landa wabah Coronavirus disease 19 (covid-19). Hal tersebut menjadi tantangan bagi dunia pendidikan, sehingga untuk memutus rantai penyebaran covid-19 maka upaya yang dilakukan adalah dengan membatasi kerumunan. Begitupun dengan sekolah yang harus melaksanakan pembelajaran tanpa tatap muka atau pembelajaran jarak jauh yang sering disebut pembelajaran dalam jaringan (daring). Pembelajaran daring merupakan pembelajaran yang dilakukan secara online dengan bantuan koneksi internet. Pembelajaran dapat dilakukan jarak jauh, tanpa bertatap muka di dalam ruangan secara langsung, dan waktunya pun terbatas (Anggraini, 2018).

Pembelajaran daring menjadi salah satu alternatif guru dalam kegiatan pembelajaran selama masa pandemi Covid-19 (Handarini \& Wulandari, 2020; Jayul \& Irwanto, 2020). Pembelajaran daring dapat dilakukan oleh guru maupun siswa kapan dan dimana saja. Menggunakan pembelajaran daring siswa tidak perlu menghabiskan waktu untuk belajar di dalam kelas seperti halnya pembelajaran tatap muka. Pembelajaran daring mempunyai kelebihan untuk memberikan informasi secara praktis. Namun demikian, pada kenyataannya pembelajaran daring bukan suatu pembelajaran yang tanpa permasalahan (Annur \& Hermasyah, 2020; Fauzy \&
Nurfauziah, 2021). Ada beberapa masalah yang dihadapi guru selama pembelajaran daring diantaranya terkait materi ajar, interaksi belajar, dan lingkungan belajar (Fortune et al., 2011).

Faktanya dalam pembelajaran daring ada beberapa kendala yang sering dihadapi guru dalam pemberian materi ajar selama pembelajaran. Oleh karena itu, guru dalam penyampaian materi selama pembelajaran daring kurang optimal. Hal ini karena guru terbatas metode ajar yang akan disampaikan. Tidak sedikit guru yang sekedar memberikan materi kepada peserta didiknya melalui pesan whatsapp (Satrianingrum \& Prasetyo, 2020). Selain itu, keterbatasan penguasaan teknologi informasi, karena tidak seluruh guru paham dalam menggunakan teknologi, terutama guru yang menjelang masa pensiun. Dari segi efektifitas pembelajaran daring juga kurang efektif karena interaksi antara guru dan siswa menjadi terbatas. Hal ini juga diungkapkan oleh (Utami \& Cahyono, 2020) pembelajaran daring atau online memiliki banyak kekurangan salah satunya kurangnya interaksi antara guru dengan peserta didik, kurangnya interaksi tersebut dapat memperlambat proses belajar mengajar. Guru yang terbiasa melakukan komunikasi secara langsung dengan peserta didik, tetapi karena pandemi Covid-19 sekarang membuat guru kesulitan untuk melakukan komunikasi secara online dengan baik (Mastura \& Santaria, 2020). Hal tersebut merupakan tantangan bagi guru di masa pandemi ini. Beberapa penelitian mengatakan bahwa pembelajaran daring mempunyai sisi postif, namun di balik hal tersebut ada juga sisi negatifnya (Taufik, 2019). 
DOI: https://doi.org/10.24127/ajpm.v10i4.3707

Pada tahun 2017 dan 2018 Nuryansyah Adijaya dan Lestanto Pudji Santosa melakukan penelitian yang mengkaji mengenai permasalahan yang mungkin muncul dalam pembelajaran daring. Aspek yang diukur meliputi materi ajar, interaksi belajar dan lingkungan belajar. Hasil penelitian menunjukkan bahwa persepsi mahasiswa dalam pembelajaran online untuk materi ajar dalam pembelajaran daring belum maksimal untuk membantu siswa selama proses pembelajaran. Untuk interaksi belajar dalam perkuliahan online persepsi mahasiswa juga belum maksimal. Oleh karena itu untuk meningkatkan kualitas lingkungan belajar dalam perkuliahan online, maka diperlukan dukungan semua pihak (Adijaya \& Santosa, 2018a).

Berdasarkan penelitian terdahulu peneliti tertarik untuk menggali permasalahan tersebut dalam bentuk persepsi guru. Kontribusi dan kebaruan dalam penelitian ini adalah menjelaskan dan mengeskplorasi persepsi guru dengan skema pembelajaran secara daring. Dimana, pembelajaran daring adalah menjadi sesuatu hal yang baru bagi Sebagian besar pendidik. Tujuan penelitian ini untuk mendeskripsikan dan mengeksplorasi persepsi guru terhadap pembelajaran daring pada mata pelajaran matematika.

\section{METODE PENELITIAN}

Jenis penelitian ini adalah kualitatif deskriptif (Purwasih \& Elshap, 2021; Wahyuniar et al., 2021). Data yang diperoleh dipaparkan dalam bentuk deskripsi mengenai persepsi guru terhadap materi ajar, interaksi belajar dan lingkungan belajar dalam pembelajaran daring.

Penelitian ini dilakukan di Daerah Istimewa Yogyakarta pada SMP dan SMA sederajat. Subjek dalam penelitian ini yaitu guru matematika SMP dan SMS sederajat di Daerah Istimewa Yogyakarta. Pengambilan sampel dilakukan dengan teknik Purposive Sampling, dan sampel yang digunakan dalam penelitian sejumlah 30 guru matematika. Metode pengumpulan data yang digunakan dalam penelitian ini yaitu dengan angket dan wawancara. Angket yang digunakan adalah angket yang disusun berdasarkan skala Likert dan menggunakan Google Form. Wawancara dilakukan pada beberapa responden terpilih untuk memperkuat data yang diperoleh melalui angket dan dilakukan melalui wawancara. Pemilihan responden yang diwawancara berdasarkan jenjang satuan pendidikan, tingkat pendidikan guru.

Penelitian ini diawali dengan menentukan indikator variabel penelitian. Kemudian, disusun menjadi instrument angket dan pedoman wawancara. Kisi-kisi angket dan wawancara terbagi menjadi tiga aspek yaitu materi ajar, interaksi belajar dan lingkungan belajar yang tersusun menjadi delapan indikator dan tiga belas butir angket. Setelah instrument tersusun selanjutnya instrument diberikan kepada validator untuk divalidasi. Setelah validator menyetujui dan instrument dikatakan valid, selanjutnya dilakukan pengambilan data. Instrument terlebih dahulu diuji cobakan untuk mengukur validitas dan reabilitas. Proses pengambilan data dilakukan dengan cara mengirimkan link angket yang telah dibuat dengan Google Form kepada responden. Setelah pengambilan data selesai, selanjutnya data yang telah diperoleh akan di analisis.

Teknik analisis data yang digunakan dalam penelitian ini adalah menggunakan langkah-langkah seperti 
yang dikemukakan oleh Miles dan Hubermen (Sugiyono, 2015) yaitu reduksi data (Data Reduction), Penyajian Data (Data Display), dan Penarikan Kesimpulan (Conclusion Drawing). Selanjutnya dilakukan keabsahan data untuk mengecek data yang didapatkan dari angket dengan data wawancara menggunakan triangulasi.

\section{HASIL DAN PEMBAHASAN}

Persepsi Guru Terhadap Aspek Materi Ajar Dalam Pembelajaran Daring

Persepsi guru terhadap materi ajar dalam pembelajaran jaringan (daring) berdasarkan jenis kelamin, lama mengajar dan tingkat pendidikan tersaji pada Tabel 1.

Tabel 1. Kecenderungan Persepsi Guru Terhadap Aspek Materi Ajar

\begin{tabular}{llllllll}
\hline \multirow{2}{*}{ Kategori } & \multicolumn{3}{c}{ Jenis Kelamin } & \multicolumn{2}{c}{ Lama Mengajar } & \multicolumn{3}{l}{$\begin{array}{l}\text { Satuan } \\
\text { Pendidikan }\end{array}$} \\
\cline { 2 - 8 } & $\begin{array}{l}\text { Laki- } \\
\text { laki }\end{array}$ & Perempuan & $\begin{array}{l}\mathbf{0 - 1 0} \\
\text { Tahun }\end{array}$ & $\begin{array}{l}\mathbf{1 1 - 2 0} \\
\text { Tahun }\end{array}$ & $\begin{array}{l}\mathbf{2 1 - 3 0} \\
\text { Tahun }\end{array}$ & SMP & SMA \\
\cline { 2 - 8 } $\begin{array}{l}\text { Sangat Tidak } \\
\text { Setuju }\end{array}$ & $0 \%$ & $0 \%$ & $0 \%$ & $0 \%$ & $0 \%$ & $0 \%$ & $0 \%$ \\
Tidak Setuju & $0 \%$ & $0 \%$ & $0 \%$ & $0 \%$ & $0 \%$ & $0 \%$ & $0 \%$ \\
Kurang Setuju & $0 \%$ & $23 \%$ & $27 \%$ & $50 \%$ & $67 \%$ & $27 \%$ & $0 \%$ \\
Setuju & $67 \%$ & $77 \%$ & $73 \%$ & $50 \%$ & $33 \%$ & $64 \%$ & $75 \%$ \\
Sangat Setuju & $33 \%$ & $0 \%$ & $0 \%$ & $0 \%$ & $0 \%$ & $9 \%$ & $25 \%$ \\
\hline
\end{tabular}

\section{Berdasarkan Tabel 1, hasil} analisis menunjukkan bahwa persepsi guru laki-laki terhadap aspek materi ajar selama pembelajaran daring sebanyak $67 \%$ setuju dan 33\% kurang setuju. Sedangkan untuk guru perempuan $23 \%$ kurang setuju dan $77 \%$ setuju. Dari hasil analisis dapat di simpulkan persepsi guru laki-laki dan perempuan terhadap aspek materi ajar selama pembelajaran daring cenderung pada kategori setuju bahwa secara umum untuk materi ajar yang diberikan selama pembelajaran daring sudah baik. Hal ini didukung oleh pendapat guru yang mengatakan bahwa terkait materi ajar yang disampaikan selama pembelajaran daring sudah direncanakan sebelumnya oleh guru dan sudah disesuaikan dengan kurikulum yang ada di sekolah sehingga materi ajar matematika tersebut sesuai dengan kebutuhan siswa dan mudah dimengerti juga oleh siswanya. Tetapi dalam penyampaian materi ajar antara guru laki-laki dan perempuan memiliki perbedaan. Guru perempuan dalam menyampaikan materi matematika lebih kreatif dan menarik dalam memilih metode, alat bantu, aplikasi dan media yang sesuai dengan materi pembelajaran sehingga siswa dapat mudah mengerti materi yang diajarkan dan sesuai dengan kondisi peserta didik, sehingga peserta didik tidak merasa jenuh. Sedangkan untuk guru laki-laki dalam menyampaikan materi ajar hanya melalui foto maupun rangkuman tulisan saja. Hal ini menyebabkan siswa sulit untuk memahami materi yang diberikan oleh guru.

Dari hasil data tersebut, dapat dilihat bahwa persepsi guru dengan lama mengajar 0-10 tahun cenderung pada kategori setuju. Hal ini di dukung oleh pendapat guru yang mengatakan bahwa guru dengan lama mengajar 0-10 tahun dalam menyampaikan materi kepada peserta didiknya lebih 
berinovasi dan kreatif, seperti memberikan materi matematika dalam bentuk video yang menarik. Sehingga materi yang diberikan diharapkan mudah di pahami oleh peserta didiknya. Sedangkan untuk persepsi guru dengan lama mengajar 11-20 tahun dan 21-30 tahun kecenderungan guru dalam kategori kurang setuju. hal ini didukung oleh pendapat guru yang mengatakan bahwa guru dengan lama mengajar 1120 tahun dan 21-30 tahun dalam pemberian materi ajar hanya memberikan materi-materi saja tanpa ada penjelasan. Hal ini karena guru tersebut kurang menguasai teknologi. Oleh karena itu dalam memberikan materi ajar matematika cenderung monoton. Jadi, dapat disumpulkan lama mengajar guru 0-10 tahun memilki pengaruh dalam aspek materi ajar. Hal ini karena guru dengan lama mengajar 0-10 tahun sebelumnya sudah pernah mengikuti pelatihan dan pengembangan teknologi. Sehingga ketika pembelajaran dilakukan secara daring seperti sekarang ini, guru lebih kreatif dalam memberikan materi kepada peserta didiknya. Contohnya dengan membuat berbagai media dan sumber belajar baik melalui Google Classroom, Quiziz, maupun channel youtube dan modul yang lebih memudahkan peserta didik untuk mengakses kapan saja untuk belajar.

Dari hasil analisis dapat disimpulkan bahwa untuk persepsi guru baik yang mengajar pada tingkat SMP maupun SMA sebagian besar guru berpendapat setuju. Hal ini didukung oleh pendapat guru baik dari guru SMP dan SMA yang mengatakan bahwa dalam menyampaikan materi ajar selama pembelajaran guru dapat menyesuaikan metode dan media pembelajaran sesuai dengan kondisi peserta didiknya. Sehingga dapat mendorong peserta didik semangat untuk lebih giat dalam belajar dan membuat peserta didik merasa tertarik untuk mengikuti kegiatan pembelajaran.

\section{Persepsi Guru Terhadap Aspek Interaksi Belajar Dalam Pembelajaran Daring \\ Persepsi guru terhadap interaksi belajar dalam pembelajaran jaringan (daring) berdasarkan jenis kelamin, lama mengajar dan tingkat pendidikan tersaji pada Tabel 2.}

Tabel 2. Kecenderungan Persepsi Guru Terhadap Aspek Interaksi Belajar

\begin{tabular}{|c|c|c|c|c|c|c|c|}
\hline \multirow{3}{*}{ Kategori } & \multicolumn{7}{|c|}{ Pengelompokan } \\
\hline & \multicolumn{2}{|c|}{ Jenis Kelamin } & \multicolumn{3}{|c|}{ Lama Mengajar } & \multicolumn{2}{|c|}{$\begin{array}{l}\text { Satuan } \\
\text { Pendidikan }\end{array}$} \\
\hline & $\begin{array}{l}\text { Laki- } \\
\text { laki }\end{array}$ & Perempuan & $\begin{array}{l}\text { 0-10 } \\
\text { Tahun }\end{array}$ & $\begin{array}{l}\text { 11-20 } \\
\text { Tahun }\end{array}$ & $\begin{array}{l}\text { 21-30 } \\
\text { Tahun }\end{array}$ & SMP & SMA \\
\hline $\begin{array}{l}\text { Sangat Tidak } \\
\text { Setuju }\end{array}$ & $0 \%$ & $0 \%$ & $0 \%$ & $0 \%$ & $0 \%$ & $9 \%$ & $0 \%$ \\
\hline Tidak Setuju & $0 \%$ & $0 \%$ & $20 \%$ & $0 \%$ & $50 \%$ & $0 \%$ & $25 \%$ \\
\hline Kurang Setuju & $50 \%$ & $69 \%$ & $53 \%$ & $50 \%$ & $50 \%$ & $55 \%$ & $0 \%$ \\
\hline Setuju & $50 \%$ & $31 \%$ & $27 \%$ & $50 \%$ & $0 \%$ & $36 \%$ & $75 \%$ \\
\hline Sangat Setuju & $0 \%$ & $0 \%$ & $0 \%$ & $50 \%$ & $0 \%$ & $0 \%$ & $0 \%$ \\
\hline $\begin{array}{l}\text { Berdasar } \\
\text { bahwa persenta } \\
\text { laki-laki terhada } \\
\text { yaitu sebanyak }\end{array}$ & in tabc & $\begin{array}{l}2 \text { ditunjukan } \\
\text { ersepsi guru } \\
\text { teraksi belajar } \\
\text { ng setuju dan }\end{array}$ & & $\begin{array}{l}\text { aksi b } \\
\text { ju dan }\end{array}$ & $\begin{array}{l}\text { edangk } \\
\text { puan } \\
\text { ar sebs } \\
1 \% \text { se }\end{array}$ & $\begin{array}{l}\text { untuk } \\
\text { rhadap } \\
\text { ak } 699 \\
\text { u. Be }\end{array}$ & $\begin{array}{r}\text { ersespsi } \\
\text { aspek } \\
\text { kurang } \\
\text { asarkan }\end{array}$ \\
\hline
\end{tabular}


hasil dari angket guru ini, menjelaskan bahwa baik dari guru laki-laki maupun guru perempuan sangat kesulitan dalam berkomunikasi dengan peserta didik. Hal ini karena guru laki-laki dan perempuan tidak bisa memberikan feedback secara baik kepada peserta didiknya. Contohnya ketika ada peserta didik belum paham terhadap materi yang disampaikan oleh guru, gurunya akan menjelaskanya serta memberikan beberapa contoh lain sehingga peserta didik akan lebih mudah paham dan yang paham akan semakin paham.

Jadi dapat disimpulkan untuk persepsi guru terhadap aspek interaksi belajar berdasarkan lama mengajar sebagian besar guru berpendapat kurang setuju. hal ini didukung oleh pendapat guru yang mengatakan bahwa jika pembelajaran matematika dilakukan secara daring interaksi yang terjadi antara guru dengan siswa itu kurang efektif. selama pembelajaran daring guru mendapatkan kesulitan dalam berinteraksi baik dengan siswa, terkadang terhambat sinyal atau jaringan internet yang berbeda-beda pada setiap siswa. Interaksi belajar akan lebih maksimal apabila pembelajaran dilakukan secara langsung sehingga guru bisa mengetahui masing-masing karakter dari siswanya. Tetapi karena dalam kondisi saat ini yang mengharuskan sosial distancing memang pembelajaran secara daring merupakan salah satu cara yang dapat digunakan dan dapat mengganti pembelajaran langsung dan hal tersebut memang sudah anjuran dari pemerintah untuk proses belajar mengajar dilakukan di rumah dengan pembelajaran daring, jadi mau tidak mau guru harus mengikuti anjuran pemerintah untuk melaksanakan pembelajaran daring atau pembelajaran jarak jauh melalui internet. Namun dalam kondisi normal disekolah tatap muka lebih dapat memudahkan untuk berinteraksi/ berkomunikasi.

Dapat disimpulkan bahwa baik dari guru SMP dan SMA persepsi guru terhadap aspek interaksi belajar cenderung dalam kategori kurang setuju. hal ini didukung oleh pendapat guru yang mengatakan bahwa interaksi yang terjadi antara guru dengan peserta didik selama pembelajaran daring tidak bisa dibilang mudah. Karena baik menggunakan pembelajaran daring maupun tatap muka memiliki kelebihan dan kekurangan masing-masing. Jika pembelajaran dilakukan secara daring guru sering terjadi miskonsepsi dengan peserta didik. Karena pada saat pembelajaran tidak semua peserta didik bisa mengikutinya. Jadi intinya pembelajaran daring tidak bisa memudahkan guru untuk berinteraksi dengan siswa.

\section{Persepsi Guru Terhadap Aspek Lingkungan Belajar Dalam Pembelajaran Daring}

Persepsi guru terhadap lingkungan belajar dalam pembelajaran jaringan (daring) berdasarkan jenis kelamin, lama mengajar dan tingkat pendidikan tersaji pada Tabel 3.

Berdasarkan Tabel 3, hasil analisis menunjukkan bahwa persepsi guru laki-laki dan perempuan terhadap aspek lingkungan belajar selama pembelajaran daring sebanyak $50 \%$ kurang setuju dan $50 \%$ setuju. sedangkan untuk guru perempuan $15 \%$ tidak setuju, $46 \%$ kurang setuju dan $38 \%$ setuju. Dapat disimpulkan bahwa untuk guru laki-laki dan perempuan cenderung pada kategori kurang setuju terhadap aspek lingkungan belajar bahwa pembelajaran daring belum mendukung peserta didik untuk belajar yang kondusif. Hal ini didukung oleh 
pendapat guru laki-laki dan perempuan yang mengatakan bahwa untuk lingkungan belajar selama pembelajaran daring kurang maksimal, selama pembelajaran dilakukan secara tatap muka saja, peserta didik sulit untuk dikondisikan apalagi sekarang yang pembelajarannya dilakukan secara daring. Ketika dengan sistem daring, jaringan internet yang tidak memadai menjadi salah satu alasan pembelajaran matematika tidak berjalan kondusif.

Tabel 3. Kecenderungan Persepsi Guru Terhadap Aspek Lingkungan Belajar

\begin{tabular}{|c|c|c|c|c|c|c|c|}
\hline \multirow{3}{*}{ Kategori } & \multicolumn{7}{|c|}{ Pengelompokan } \\
\hline & \multicolumn{2}{|c|}{ Jenis Kelamin } & \multicolumn{3}{|c|}{ Lama Mengajar } & \multicolumn{2}{|c|}{$\begin{array}{l}\text { Satuan } \\
\text { Pendidikan }\end{array}$} \\
\hline & & Perempuan & -10 & & & SMP & SMA \\
\hline \multirow{5}{*}{$\begin{array}{l}\text { Sangat Tidak } \\
\text { Setuju } \\
\text { Tidak Setuju } \\
\text { Kurang Setuju } \\
\text { Setuju } \\
\text { Sangat Setuju }\end{array}$} & 0 & & & $0 \%$ & $0 \%$ & $0 \%$ & \\
\hline & 0 & & & & $0 \%$ & $\%$ & \\
\hline & $50 \%$ & & & $\%$ & $50 \%$ & 36 & \\
\hline & $50 \%$ & & & $\%$ & $0 \%$ & $55^{c}$ & \\
\hline & $0 \%$ & $0 \%$ & & $0 \%$ & $0 \%$ & $0 \%$ & 070 \\
\hline \multirow{12}{*}{\multicolumn{3}{|c|}{$\begin{array}{l}\text { Dari hasil analisis dapat } \\
\text { disimpulkan bahwa lama mengajar guru } \\
\text { tidak mempengaruhi aspek lingkungan } \\
\text { belajar. Hal ini karena selama } \\
\text { pembelajaran matematika dengan } \\
\text { sistem daring guru mengalami kesulitan } \\
\text { untuk mengkondisikan siswanya. Guru } \\
\text { juga berpendapat bahwa hal yang } \\
\text { membuat lingkungan belajar daring } \\
\text { tidak kondusif salah satunya adalah } \\
\text { tidak semua orang tua siswa } \\
\text { mendampingi anaknya dalam } \\
\text { pembelajaran daring di rumah karena } \\
\text { orang tua juga harus bekerja, jadi } \\
\text { terkadang sulit untuk memantau siswa } \\
\text { sehingga kurang tercipta suasana belajar } \\
\text { yang kondusif. }\end{array}$}} & \multirow{18}{*}{\multicolumn{5}{|c|}{$\begin{array}{l}\text { Santosa, 2018a). Kendala yang } \\
\text { dirasakan meliputi penyampaian materi } \\
\text { ajar dan media pembelajaran. Guru } \\
\text { yang masih kesulitan dalam hal } \\
\text { mengoperasikan teknologi. Sehingga } \\
\text { dalam menyampaikan materi ajar guru } \\
\text { hanya melalui whatshap atau google } \\
\text { form. Sehingga dirasa kurang bervariasi. } \\
\text { Untuk persepsi guru terhadap interaksi } \\
\text { belajar dalam pembelajaran daring } \\
\text { dapat disimpulkan bahwa interaksi } \\
\text { belajar antara guru dengan siswa dalam } \\
\text { pembelajaran daring belum maksimal. } \\
\text { Hal ini selaras dengan penelitian yang } \\
\text { dilakukan oleh Adijaya dan Santosa } \\
\text { pada tahun 2018 yang mengatakan } \\
\text { bahwa jaringan internet menjadi } \\
\text { masalah utama dalam pembelajaran } \\
\text { daring (Adijaya \& Santosa, 2018a). } \\
\text { Dengan jaringan internet yang kurang } \\
\text { lancar dapat menghambat } \\
\text { berlangsungnya interaksi anatara guru } \\
\text { dengan peserta didik selama } \\
\text { pembelajaran daring. }\end{array}$}} \\
\hline & & & & & & & \\
\hline & & & & & & & \\
\hline & & & & & & & \\
\hline & & & & & & & \\
\hline & & & & & & & \\
\hline & & & & & & & \\
\hline & & & & & & & \\
\hline & & & & & & & \\
\hline & & & & & & & \\
\hline & & & & & & & \\
\hline & & & & & & & \\
\hline \multirow{2}{*}{\multicolumn{3}{|c|}{$\begin{array}{l}\text { Dari hasil penelitian tentang } \\
\text { eersepsi guru terhadap aspek materi ajar }\end{array}$}} & & & & & \\
\hline & & & & & & & \\
\hline \multicolumn{3}{|c|}{$\begin{array}{l}\text { dalam pembelajaran daring dapat } \\
\text { disimpulkan bahwa pembelajaran }\end{array}$} & & & & & \\
\hline \multirow{3}{*}{\multicolumn{3}{|c|}{$\begin{array}{l}\text { daring memudahkan guru dalam } \\
\text { menyampaikan materi ajar. Hasil } \\
\text { penelitian ini memiliki perbedaan }\end{array}$}} & & & & & \\
\hline & & & & & & & \\
\hline & & & & & & & \\
\hline \multicolumn{3}{|c|}{ dengan penelitian yang dilakukan oleh } & \multirow{3}{*}{\multicolumn{5}{|c|}{$\begin{array}{l}\text { belajar dalam pembelajaran daring } \\
\text { dapat disimpulkan bahwa lingkungan } \\
\text { belajar saat pembelajaran daring belum }\end{array}$}} \\
\hline \multicolumn{3}{|c|}{$\begin{array}{l}\text { Adijaya dan Santosa pada tahun } 2018 \\
\text { yang mengatakan bahwa pembelajaran }\end{array}$} & & & & & \\
\hline & & & & & & & \\
\hline
\end{tabular}


mendukung guru maupun siswa untuk kondusif, misalnya terkait sarana dan prasarana yang dimiliki guru maupun siswa berbeda-beda. Oleh karena itu untuk meningkatkan kualitas lingkungan belajar dalam pembelajaran daring maka diperlukan dukungan semua pihak. Hal ini juga selaras dengan penelitian yang dilakukan oleh (Hidayah, A. F., Adawiyah, R. A., \& Mahanani, 2020) dan (Adijaya \& Santosa, 2018b) yang mengatakan bahwa lingkungan belajar saat pembelajaran saat ini belum kondusif. Hal ini karena penggunaan smartphone yang harus bergantian dengan anggota keluarga menjadi kendala yang signifikan. Sehingga guru sulit untuk menciptakan suasan yang efektif selama pembelajaran daring.

bukti $\begin{gathered}\text { Penelitian ini menambahkan } \\ \text { empiris bahwa persepsi }\end{gathered}$ pembelajaran daring dimata guru dianggap tidak efektif (Satrianingrum \& Prasetyo, 2020). Hal ini karena pembelajaran tatap muka belum belum bisa tergantikan secara efektif dengan pembelajaran daring (Baety \& Munandar, 2021; Dewantara \& Nurgiansah, 2020; Kusumaningrum \& Wijayanto, 2020). Selain itu juga dipengaruhi oleh beberapa faktor yang menyebabkan pembelajaran daring belum efektif diantaranya keterbatasan sarana dan prasarana yang dimiliki siswa maupun guru, keterbatasan guru dalam menguasai IT sehingga materi yang diberikan selama pembelajaran belum sesuai dengan tujuan pembelajaran. Selain itu penelitian yang dilakukan oleh (Anggianita et al., 2020) juga berpendapat bahwa persepsi guru terhadap pembelajaran daring masih kurang efektif. Pembelajaran daring membuat guru kurang optimal dalam penyampaian materi yang akan disampaikan kepada siswanya. Hal ini karena guru tidak leluasa dalam berinteraksi seperti dikelas. Selain itu jaringan yang lamban juga merupakan faktor yang menyebabkan kurang efektifnya pembelajaran daring. Tetapi, penelitian lain mengungkapkan bahwa pembelajaran daring juga efektif hanya saja harus memenuhi sepuluh aspek kelengkapan dalam pembelajaran daring. Aspek tersebut meliputi: Video call/tatap muka virtual, ringkas, hemat kuota, bahasa yang mudah dimenegerti, sebelum penugasan disampaikan materi terlebih dahulu, soal yang variatif, tugas dilengkapi dengan prosedur kerja, sesuai jadwal, pengingat jika ada tugas dan mengurangi beban tugas berlebih (Mustakim, 2020).

Penelitian ini mengungkap fakta bahwa ada dua aspek yang dinilai kurang oleh guru yaitu aspek interaksi belajar dan mengenai lingkungan belajar. Tentu hal ini menjadi perhatian serius bagi dinas pendidikan terkait, sekolah dan orang tua. Dalam pembelajaran daring dua aspek tersebut harus segera dicari titik solusi agar pembelajaran dan transfer pengetahuan tetap berjalan sebagai mana mestinya.

\section{KESIMPULAN DAN SARAN}

Berdasarkan hasil penelitian dapat disimpulkan persepsi guru terhadap aspek materi ajar berdasarkan jenis kelamin, lama mengajar dan satuan pendidikan selama pembelajaran daring dalam kategori baik. Hal ini karena pembelajaran daring memudahkan guru dalam menyampaikan materinya selama proses belajar mengajar.

Persepsi guru terhadap aspek interaksi belajar berdasarkan jenis kelamin, lama mengajar dan satuan pendidikan dalam kategori kurang. Hal ini di perkuat oleh pendapat guru yang mengatakan bahwa selama 
pembelajaran daring proses pembelajaran tidak secara langsung dipantau oleh guru sehingga interaksi guru dan peserta didik menjadi terbatas dan tidak bisa melihat bagaimana keadaan peserta didik yang sebenarnya. Persepsi guru terhadap lingkungan belajar berdasarkan jenis kelamin, lama mengajar dan satuan pendidikan kurang maksimal. Hal ini karena lingkungan belajar selama pembelajaran daring belum mendukung siswa untuk belajar secara kondusif dan efektif. Oleh karena itu untuk meningkatkan kualitas lingkungan belajar dalam pembelajaran daring, maka diperlukan dukungan semua pihak.

\section{DAFTAR PUSTAKA}

Adijaya, N., \& Santosa, L. P. (2018a). Persepsi Mahasiswa dalam Pembelajaran Online. Wanastra Jurnal, 10(2), 105-110.

Adijaya, N., \& Santosa, L. P. (2018b). Persepsi Mahasiswa Dalam Pembelajaran Online. 10(2).

Anggianita, S., Yusnira, \& Rizal, M. S. (2020). Persepsi Guru terhadap Pembelajaran Daring di Sekolah Dasar Negeri 013 Kumantan. Journal of Education Research, l(2), 177-182. https://doi.org/https://doi.org/10.37 985/joe.v1i2.18

Anggraini, A. (2018). Keefektifan Pembelajaran Elektronik (ELearning) Sebagai Pengganti Perkuliahan Konvensional Untuk Meningkatkan Kemampuan Analitis Mahasiswa. Jurnal Sosial Humaniora, 9(2), 95-105. https://doi.org/http://dx.doi.org/10. 30997/jsh.v9i2.1101

Annur, M. F., \& Hermasyah. (2020). Analisis Kesulitan Mahasiswa Pendidikan Matematika Dalam
Pembelajaran Daring Pada Masa Pandemi Covid-19. Jurnal Kajian, Pnelitian Dan Pengembangan Kependidikan, 11(2), 195-201.

Baety, D. N., \& Munandar, D. R. (2021). Analisis Efektifitas Pembelajaran Daring dalam Menghadapi Wabah Pandemi COVID-19. EDUKATIF: Jurnal Ilmu Pendidikan, 3(3), 880-889.

Dewantara, J. A., \& Nurgiansah, T. H. (2020). Efektivitas Pembelajaran Daring di Masa Pandemi COVID 19 Bagi Mahasiswa Universitas PGRI Yogyakarta. Jurnal Basicedu, 5(1), 367-375. https://doi.org/10.31004/basicedu.v 5 i1.669

Fauzy, A., \& Nurfauziah, P. (2021). Kesulitan Pembelajaran Daring Matematika Pada Masa Pandemi COVID-19 di SMP Muslimin Cililin. Jurnal Cendekia: Jurnal Pendidikan Matematika, 5(1), 551-561.

https://doi.org/10.31004/cendekia. v5i1.514

Fortune, M. F., Spielman, M., \& Pangelinan, D. T. (2011). Students' Perceptions of Online or Face-toFace Learning and Social Media in Hospitality, Recreation and Tourism. MERLOT Journal of Online Learning and Teaching.

Handarini, O. I., \& Wulandari, S. S. (2020). Pembelajaran Daring Sebagai Upaya Study From Home (SFH) Selama Pandemi Covid 19. Jurnal Pendidikan Administrasi Perkantoran (JPAP), 8(3), 496503.

https://doi.org/10.1093/fampra/cm y005

Hidayah, A. F., Adawiyah, R. A., \& Mahanani, P. R. (2020). No Title. Jurnal Penelitian Ilmu-Lmu Sosial, $21,2$. 
Jayul, A., \& Irwanto, E. (2020). Model Pembelajaran Daring Sebagai Alternatif Proses Kegiatan Belajar Pendidikan Jasmani di Tengah Pandemi Covid-19 Achmad. Jurnal Pendidikan Kesehatan Rekreasi, 6(2), 190-199. https://doi.org/10.5281/zenodo.389 2262

Kusumaningrum, B., \& Wijayanto, Z. (2020). Apakah Pembelajaran Matematika Secara Daring Efektif? (Studi Kasus pada Pembelajaran Selama Masa Pandemi Covid-19). Kreano, Jurnal Matematika Kreatif-Inovatif, 11(2), 139-146. https://journal.unnes.ac.id/nju/inde x.php/kreano/article/view/25029

Mastura, \& Santaria, R. (2020). Dampak Pandemi Covid-19 terhadap Proses Pengajaran bagi Guru dan Siswa. Jurnal Studi Guru Dan Pembelajaran, 3(2), 634. https://doi.org/https://doi.org/10.30 605/jsgp.3.2.2020.293

Mustakim, M. (2020). Efektivitas Pembelajaran Daring Menggunakan Media Online Selama Pandemi Covid-19 Pada Mata Pelajaran Matematika. $A l$ Asma: Journal of Islamic Education, $\quad 2(1), \quad 1$. https://doi.org/10.24252/asma.v2i1 .13646

Mutia, I., \& Leonard, L. (2013). Kajian Penerapan E-Learning Dalam Proses Pembelajaran di Perguruan Tinggi. Faktor Exacta, 6(4), 278289.

Purwasih, R., \& Elshap, D. S. (2021). Belajar Bersama Covid-19:Review Impelementasi, Tantangan Dan Solusi Pembelajaran Daring Pada Guru-Guru Smp. AKSIOMA: Jurnal Program Studi Pendidikan Matematika, 10(2), 940-950.
Satrianingrum, A. P., \& Prasetyo, I. (2020). Persepsi Guru Dampak Pandemi Covid-19 terhadap Pelaksanaan Pembelajaran Daring di PAUD. Jurnal Obsesi : Jurnal Pendidikan Anak Usia Dini. https://doi.org/10.31004/obsesi.v5i 1.574

Sugiyono. (2015). Metode Penelitian Pendidikan (Pendekatan Kuantitatif, Kualitatif, dan $R \& D$ ). Alfabeta.

Taufik, A. (2019). Perspektif Tentang Perkembangan Sistem Pembelajaran Jarak Jauh Di Kabupaten Kutai Kartanegara Kalimantan Timur. Jurnal Pendidikan\&Konseptual. http://doi.org/10.28926/riset_konse ptual.v2i4.111

Utami, Y. P., \& Cahyono, D. A. D. (2020). Study at home: Analisis Kesulitan Belajar Matematika pada Proses Pembelajaran Daring. Jurnal Ilmiah Matematika Realistik (JI-MR), 1(1), 20-26. https://doi.org/https://doi.org/10.33 365/ji-mr.v1i1.252

Wahyuniar, L. S., Rochana, S., Mahdiyah, U., Shofia, N., \& Widodo, S. (2021). Pengaruh Pembelajaran Daring Dengan Google Classroom dan Google Meet Terhadap Minat Belajar Matematika Diskrit. AKSIOMA: Jurnal Program Studi Pendidikan Matematika, 10(2), 1063-1073. 